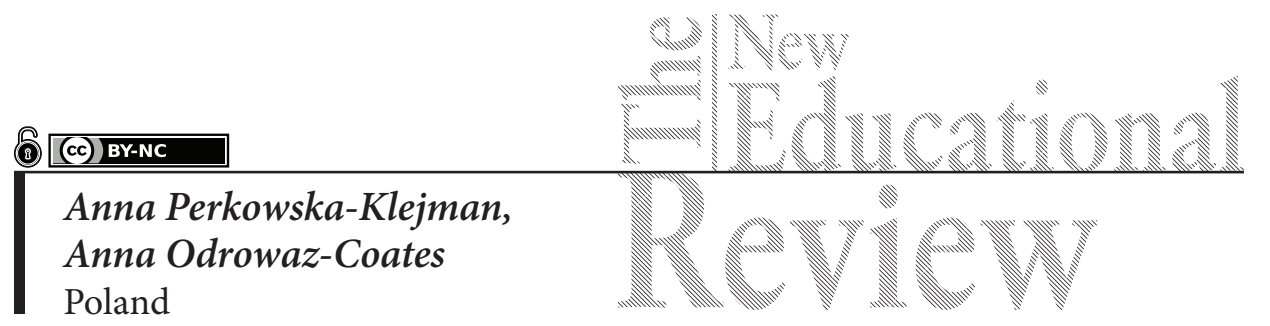

\title{
Measuring the Unmeasurable? Differences in Reflexive Thinking among Polish Students
}

DOI: 10.15804/tner.2019.55.1.06

\begin{abstract}
The paper contains advanced statistical analysis, original methods and a significant contribution to the claim that measurement of reflexivity is possible. It is based on original empirical research using a sample of 334 students from different faculties and educational levels. It utilises a qualitative questionnaire containing a 4-level reflexivity scale, designed by Kember et al. (2000), translated into the Polish language and context. The aim of the study was to identify whether students' reflexivity levels can be associated with the level of their study, taking into account possible masking effects of their age. Differences were tested for faculty and system of training (full time or part-time). Analysis confirms the strongest relation between reflexive thinking, system of tuition and level of studies. There was no connection found between reflexive thinking and the faculty of study or the respondents' gender.
\end{abstract}

Keywords: reflexivity, higher education, habitual action

\section{Introduction}

The development of reflexivity amongst students has become a prime goal of higher education in the West (Boud, et al. 1985; Thorpe, 2004). According to Rogers (2001: 55), reflexivity has become a fundamental skill in higher education, essential for the sustainable development of universities (Dawe, et al. 2005). The role 
of higher education in intensifying students' reflexivity is growing in popularity amongst researchers and this is shown by the large number of tools dedicated to the assessment of reflexivity in individuals (cf., Schön 1983, Franklin \& Langford 2002; Groningen, 2008; Mirzaei, 2014; Grant 2015). For the purposes of this study, an operational definition of reflexive thinking combining Dewey (1933), Mezirow (1991), Baxter Magolda (1992) and Kember et al. (2000) was established. Reflexive thinking is a complex and deep process of thought, which involves a degree of doubt, uncertainty and open-mindedness to enhance the process of learning, through searching for answers to complicated and often ambiguous issues. Moreover, it includes one's ability to reflect on their own thinking, to understand the process of thought, to improve it and to reason better in defense of the conclusions (cf., Paul \& Elder 2002).

\section{Research Focus}

The researchers studied students' attitudes to their own education, how they think and how they construct their academic experiences. The key objective of the project was to establish if and to what degree the reflexivity of the students participating in the project was associated with selected educational categories. These categories included: the faculty of study, the system of study and the level of study. Students' reflexivity was described at four levels: habitual action, understanding, reflection and critical reflection. The faculties were divided into: humanities and social sciences, physical science and technology, and biological and medical sciences. The system of study was full time or part-time. The levels of study covered bachelor's, master's degrees and doctoral candidates. The additional factors considered were the research participants' age and sex. The independent variables for statistical analysis were the faculty of study, level of study and system of study, together with the participants' age and sex. The dependent variables were the scores on the scales of reflexive thinking. The main research question presented in this paper was: To what extent is a student's reflexive thinking affected by the faculty, level of study and system of study?

\section{Research Methodology}

\section{Research General Background}

Reflexivity scales derived from Mezirow's (1991) theory of transformative learning and Baxter Magolda's (1992) students' learning stages, was combined with Kember's et al. (2000) classification and divided into: habitual action, under- 
standing, reflection and critical reflection. These scales were incorporated into the Questionnaire to measure the Level of Reflective Thinking (QRT) designed by Kember et al. (2002) and adapted to fit the Polish specific circumstances, which was essential for the validation of the original scales. The adaptation work took three years, first the Polish translation was looped back into English to detect any discrepancies and language adjustment took place, then psychometric equivalence was tested on bi-lingual people with both versions of the QRT. Finally, reliability of individual scales was tested using the Cronbach Alpha coefficient, which ranged from .75 to .86 for each scale. A secondary validity test relied on the high correlation of scores between questions in Polish and in English belonging to the same scale. Furthermore, a question correlation matrix was constructed, which showed that questions from the same scale always gave a statistically significant correlation result when measured with Pearson's formula. The correlations between questions from neighboring scales were statistically insignificant. For example, question 1 correlates statistically significantly with question $5(.586, \mathrm{p}<.01)$, question $9(.665$, $\mathrm{p}<.01)$, and question $13(.517, \mathrm{p}<.01)$ on the same scale.

Meanwhile, the original QRT was also tested by Persian researchers (Ghanizadeh, \& Jahedizadeh, 2017) for validity and reliability after translation and use in a different cultural context and the results were positive, confirming that the scales may be used successfully outside of their origin. Similar procedures were adopted by Kalk, Luik, Taimalu \& Täht, (2014) in Estonia, Başol and \& Gencel (2013) in Turkey and Lucas \& Leng Tan, (2006) in England.

\section{Instruments and Procedures}

The statements used in the questionnaire were constructed in a universal way and may be applied to any academic subject because they lack any discipline-specific scientific terminology. The QRT consists of 16 statements, designed to capture the ways in which students think and act. The statements were scored by the respondents using a five-point Likert scale. The statements were divided into the four categories stated above: habitual action (example statement in this category: "In this course we do things so many times that I started doing them without thinking about it", "As long as I can remember handout material for examinations, I do not have to think too much"), understanding (e.g., "In this course you have to continually think about the material you are being taught", "I need to understand the material taught by the teacher in order to perform practical tasks"), reflection (e.g., "I often reflect on my actions to see whether I could have improved on what I did", "I like to think over what I have been doing and consider alternative ways of doing it.") and critical reflection (e.g., "As a result of this course, I have changed the way I look at 
myself", "During this course I discovered faults in what I had previously believed to be right"). The statements were placed in a random order in the questionnaire. The study of reflexive thinking levels relied on self-description, capturing students' reflection on their activity in the process of study, self-awareness and active engagement.

\section{Sample}

The sample was selected on quota basis, using criteria of: faculty, level of studies and system of studies in equal proportions. The sample consisted of male and female higher education students aged 19-60, with a proportionate sex ratio to that at the subjects' faculties of study.

Table 1. Study group (application of quota sampling)

\begin{tabular}{|c|c|c|c|c|}
\hline $\begin{array}{l}\text { Faculty of study } \\
\text { (first quota selection } \\
\text { criterion) }\end{array}$ & $\begin{array}{l}\text { Humanities and } \\
\text { Social } \\
n=123\end{array}$ & $\begin{array}{l}\text { Technical and } \\
\text { Scientific } \\
n=101\end{array}$ & $\begin{array}{l}\text { Biological and } \\
\text { Medical } \\
\mathrm{n}=110\end{array}$ & $\begin{array}{l}\text { Total } \\
\mathrm{n}=334\end{array}$ \\
\hline $\begin{array}{l}\text { Target degree } \\
\text { (second quota selec- } \\
\text { tion criterion) }\end{array}$ & $\begin{array}{l}\text { Bachelor } n=45 \\
\text { Master } n=45 \\
\text { PhD } n=33\end{array}$ & $\begin{array}{l}\text { Bachelor } n=35 \\
\text { Master } n=33 \\
\text { PhD } n=33\end{array}$ & $\begin{array}{l}\text { Bachelor } \mathrm{n}=38 \\
\text { Master } \mathrm{n}=38 \\
\text { PhD } \mathrm{n}=34\end{array}$ & $\begin{array}{l}\text { Bachelor } n=118 \\
\text { Master } n=116 \\
\text { PhD } n=100\end{array}$ \\
\hline $\begin{array}{l}\text { System of study } \\
\text { (third quota selection } \\
\text { criterion) }\end{array}$ & $\begin{array}{l}\text { Full time } n=74 \\
\text { Part-time } n=49\end{array}$ & $\begin{array}{l}\text { Full time } n=65 \\
\text { Part-time } n= \\
36\end{array}$ & $\begin{array}{l}\text { Full time } n=89 \\
\text { Part-time } n= \\
21\end{array}$ & $\begin{array}{l}\text { Full time } n=228 \\
\text { Part-time } \\
n=106\end{array}$ \\
\hline $\begin{array}{l}\text { Sex (without selec- } \\
\text { tion criterion) }\end{array}$ & $\begin{array}{l}\text { Male } n=37 \\
\text { Female } n=86\end{array}$ & $\begin{array}{l}\text { Male } n=44 \\
\text { Female } n=57\end{array}$ & $\begin{array}{l}\text { Male } n=31 \\
\text { Female } n=79\end{array}$ & $\begin{array}{l}\text { Male } n=112 \\
\text { Female } n=222\end{array}$ \\
\hline
\end{tabular}

\section{Data Analysis}

The minimum number of questionnaires for necessary statistical analysis was 300. Participants were selected in accordance with principles of availability and proportionate representation of diverse faculties. All participants took a conscious decision to participate, confirmed in writing. The sample size enabled groups of participants to be compared in a similar manner to Lim (2009), Louise \& Musolino (2011), Phan (2009) and Lethbridge (2013). The chosen number of participants helped to minimise error and to enable regression analysis, multivariate analysis of variance ANOVA and ANCOVA. The sample used is not representative of all Polish students but it is to test correlation of selected variables in higher education with reflexivity. 


\section{Research Results}

\section{Reflexivity and level of study}

Analysis shows several relationships between the level of reflexivity measured on four scales and the level of study. When grouped by the level of study, the students scored differently on the habitual action scale $(\mathrm{F}=12.03, \mathrm{p}=.01)$. Multiple comparisons confirmed differences between the doctoral students, who scored significantly lower on the habitual action scale than the bachelor's course students (LSD [least significant differences] $=-.48, \mathrm{p}<.01$ ) and the master's level students (LSD $=-.28, \mathrm{p}<.01)$. There were no significant differences on the scale of understanding $(\mathrm{F}=.84, \mathrm{p}=.48)$. Moreover, a statistically valid difference between mean scores on the reflection scale was observed $(\mathrm{F}=17.83, \mathrm{p}<.01)$; a discrepancy between the doctoral and bachelor's students ( LSD $=.58, \mathrm{p}<.01)$ and doctoral and master's students (LSD $=.45, \mathrm{p}=.01)$. Critical reflection was also differentiated by the level of study $(\mathrm{F}=20.06, \mathrm{p}<.01)$. The group of doctoral students scored higher than others. The result of multiple regression shows significant difference between the doctoral and bachelor's students (LSD $=.67, \mathrm{p}<.01$ ) and between the doctoral and master's students (LSD $=.52, \mathrm{p}<.01)$.

The doctoral students display higher levels of reflexivity than the master's and bachelor's course students, indicating that the highest levels of reflexivity develop at the third level of tertiary education. However, this unsurprising conclusion was not yet fully confirmed, until the impact of age was also considered. Therefore, a correlation between age and reflexivity scores was tested to assess if the age of

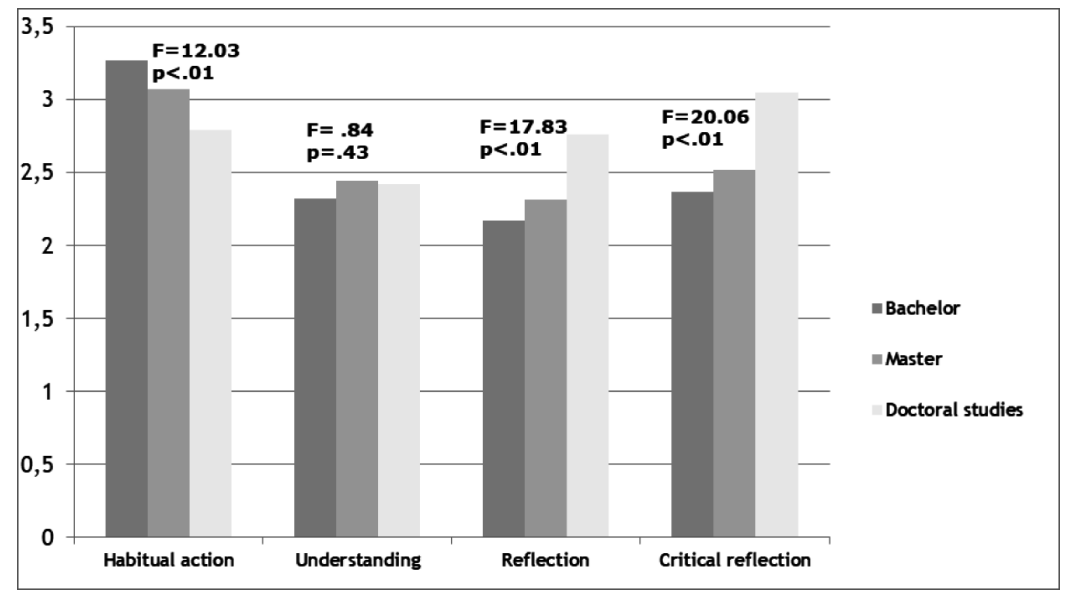

Figure 1. The level of study and the level of reflexive thinking 
the research participants was a masking factor when assessing correlation between reflexivity and the level of study. The mean age amongst the bachelor's students was $\mathrm{M}=23.17, \mathrm{SD}=4.08$, amongst the master's students $\mathrm{M}=24.55, \mathrm{SD}=3.92$ and amongst the doctoral students $\mathrm{M}=28.74, \mathrm{SD}=5.38$. The latter group was most diverse in terms of age, where the youngest doctoral student was 22 and the oldest was 60.

\section{Age}

A multiple regression technique with a GLM (General Linear Model) was used for further analysis. The level of study was the classifying variable and age was the continuous variable. Results obtained for each of the scales (treated as a separate variable) are shown in Table 2.

Table 2. The level of study, age and the level of reflexive thinking (ANCOVA)

\begin{tabular}{lllll}
\hline $\begin{array}{c}\text { Level of } \\
\text { reflective } \\
\text { thinking }\end{array}$ & Habitual action & Understanding & Reflection & $\begin{array}{c}\text { Critical Reflec- } \\
\text { tion }\end{array}$ \\
\hline $\begin{array}{l}\text { The level of } \\
\text { study }\end{array}$ & $\mathrm{F}=14.24, \mathrm{p}<.01$ & $\mathrm{~F}=1.08, \mathrm{p}<.33$ & $\mathrm{~F}=15.06, \mathrm{p}<.01$ & $\mathrm{~F}=14.16, \mathrm{p}<.01$ \\
\hline Age & $\mathrm{F}=4.32, \mathrm{p}=.03$ & $\mathrm{~F}=.61, \mathrm{p}=.43$ & $\mathrm{~F}=.17, \mathrm{p}=.67$ & $\mathrm{~F}=.40, \mathrm{p}=.52$ \\
\hline $\begin{array}{l}\text { The level of } \\
\text { study and age }\end{array}$ & $\mathrm{F}=9.54, \mathrm{p}<.01$ & $\mathrm{~F}=.76, \mathrm{p}=.51$ & $\mathrm{~F}=11.92, \mathrm{p}<.01$ & $\mathrm{~F}=13.49, \mathrm{p}<.01$ \\
\hline
\end{tabular}

The level of study is a differentiating factor for habitual action, reflection and critical reflection. Whilst age is the differentiating factor for habitual action, it is not for reflection and critical reflection, where the results are not statistically significant. Therefore, age (on its own) cannot be considered a significant variable responsible for reflection and critical reflection.

\section{Reflexivity and the faculty of study}

The results in Figure 2 indicate that the scores for habitual action, understanding, reflection and critical reflection remain at a similar level for all the three groups of students, notwithstanding the faculty of study, although the critical reflection scores for these groups were close to being statistically significant. Analysis of variance indicates overall group diversification, but does not identify which two groups are different in terms of the measured variables. To clarify this, an LSD test was used and in two cases the results were statistically significant. The technical and science students obtained higher mean scores on the scale of understanding, 


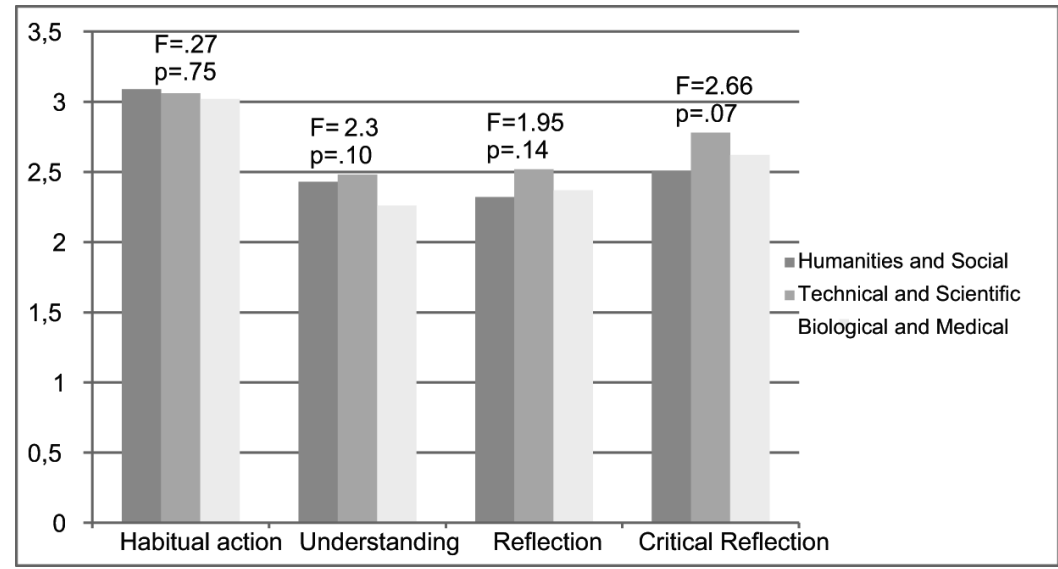

Figure 2. The faculty and reflexive thinking of students

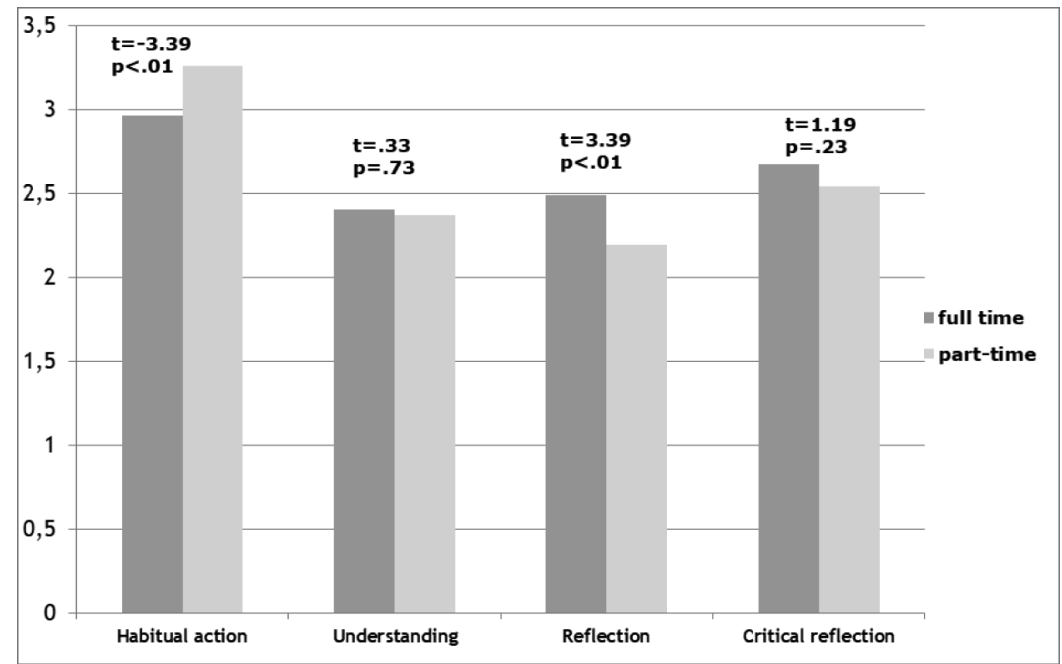

Figure 3. Study system and reflexive thinking amongst students

when compared to the biological and medical students (LSD $=.21, \mathrm{p}=.04)$. Moreover, the technical and science students obtained higher mean scores on critical reflection than the humanities and social science students $(\mathrm{LSD}=.26, \mathrm{p}=.02)$.

\section{Reflexivity and the system of study (full time or part-time)}

One of the research questions tested the correlation between reflexivity and the system of study (full or part-time). A T-test was used to compare scale scores for 
these two groups. The results of the T-test showed that the system of study was a differentiating variable on two scales: habitual action, where the part-time students obtained higher statistical mean scores than the full-time students $(t=-3.39$ $\mathrm{p}<.01$ ), and reflection scale, where the full time students obtained statistically higher mean scores than their part-time counterparts $(\mathrm{t}=3.39 \mathrm{p}<.01)$

\section{Sex}

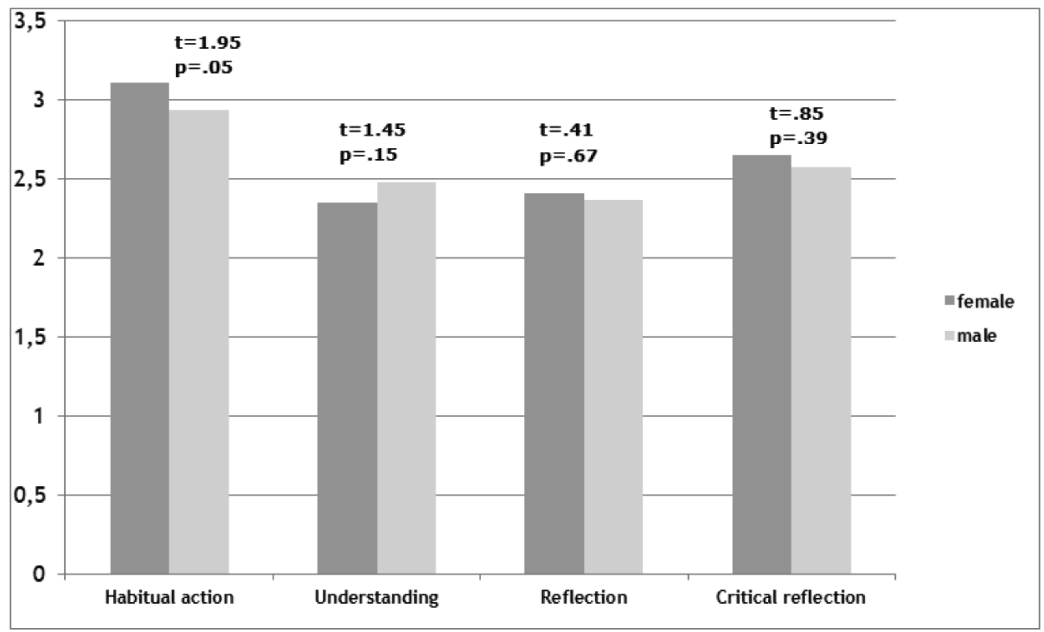

Figure 4. Sex and reflexive thinking amongst students

The participants' sex proved not to be a differentiating factor. Although habitual action scores for the male and female students was nearing statistical significance, it was considered incidental.

\section{Predictors of reflexive thinking}

Additionally, regression testing was used to test whether the variables such as the level of study, age, faculty, system of study and participants' sex, could be a predictor of students' reflexivity levels on the four scales used in this study.

There was no surprise that the level of study proved to be a predictor of habitual action, which decreased with the higher level of study; and reflection and critical reflection that were on the rise consequently with the higher level of study, consistently with the previous tests. 
Table 3. The predictor of reflexive thinking (regression analysis)

\begin{tabular}{llllll}
\hline $\begin{array}{c}\text { Level of reflec- } \\
\text { tive thinking }\end{array}$ & $\begin{array}{c}\text { The level of } \\
\text { study }\end{array}$ & \multicolumn{1}{c}{ Age } & $\begin{array}{c}\text { Faculty of } \\
\text { study }\end{array}$ & Study system & Sex \\
\hline Habitual action & $\beta=-.26$, & $\beta=.09$, & $\beta=-.01$, & $\beta=.08$, & $\beta=-.04$, \\
& $\mathrm{p}<.01$ & $\mathrm{p}=.12$ & $\mathrm{p}=.87$ & $\mathrm{p}=.17$ & $\mathrm{p}=.51$ \\
\hline Under-standing & $\beta=-.08$, & $\beta=-.07, \mathrm{p}$ & $\beta=-.09$, & $\beta=.01$, & $\beta=.06$, \\
& $\mathrm{p}=.25$ & $=.27$ & $\mathrm{p}=.08$ & $\mathrm{p}=.08$ & $\mathrm{p}=.28$ \\
\hline Reflection & $\beta=.28$, & $\beta=.01$, & $\beta=.01$, & $\beta=-.10$, & $\beta=-.12$, \\
& $\mathrm{p}<.01$ & $\mathrm{p}=.79$ & $\mathrm{p}=.92$ & $\mathrm{p}=.10$ & $\mathrm{p}=.03$ \\
\hline Critical Reflec- & $\beta=.33$, & $\beta=.05$, & $\beta=.05$, & $\beta=.04$, & $\beta=-.12$, \\
tion & $\mathrm{p}<.01$ & $\mathrm{p}=.41$ & $\mathrm{p}=.30$ & $\mathrm{p}=.51$ & $\mathrm{p}=.03$ \\
\hline
\end{tabular}

Controversially, in this study the mean results for the female participants were higher when compared with their male peers. On the reflection scale: the men's mean was $\mathrm{M}=2.37(\mathrm{SD}=.82)$ and the women's $\mathrm{M}=2.41(\mathrm{SD}=.77)$; whilst the men's mean on the critical reflection scale was $\mathrm{M}=2.57(\mathrm{SD}=.75)$ and the women's $\mathrm{M}=2.66$ ( $\mathrm{SD}=.90)$. In regression analysis, positive $(+)$ or negative $(-)$ result had no significance as sex was not a gradual variable.

\section{Discussion}

The hypothesis that the highest level of reflexive thinking, critical reflexivity, would be achieved by doctoral students was verified. The research results correspond to previous studies of this topic, where reflexive thinking was shown as a developmental category increased by age and the level of study (Boyd, 2008; Fischer, Pruyne, 2002; King, Kitchener, 2004). There were, however, some deviations from this tendency, where reflexive thinking was demonstrated by the students at lower levels of education and non-reflexive thinking by the students at higher levels. In a study dedicated to the constructivist approach to learning by Yuen Lie Lim (2011), the highest scores on the reflection and critical reflection scales were observed amongst first year students, whilst the lowest scores on habitual action were found amongst third year students. Kember's et al. (2002) study showed higher scores amongst postgraduate students when set against undergraduates on the understanding scale $(\mathrm{t}=2,58 ; \mathrm{p}<.01)$, reflection $(\mathrm{t}=5,45 ; \mathrm{p}<.01)$ and critical reflection $(t=2,83 ; \mathrm{p}<.01)$. Moreover, Naghdipour \& Emeagwali (2013) compared the means for second, third and fourth year students proving an increase in critical reflection, reflection and understanding coherent with the year of study. 


\section{Correlation between reflexive thinking and faculty of study}

The students' scores on all of the scales, regardless of their faculty of study, did not vary in a statistically significant way. Previous research on students' reflexivity did not draw comparisons between faculties of study, although QRT as a universal tool of data collection allows for such comparisons, as it was used to measure reflexivity amongst students of: mathematics by Kadivar et al. (2012), undergraduates of real estate studies by Amidu (2012), students of accounting and business by Lucas and Tan (2006), students of English (as the foreign language) by Ghanizadeh, Jahedizadeh (2017), prospective primary teachers by Espinoza \& Mata (2008) and medical students by Kember (2000).

\section{Correlation between reflexive thinking and system of study}

There were no assumptions made whether students' reflexivity is affected by studying full time or part-time. Concurrently, statistically valid differences were found between the two groups on the scale of habitual action and the scale of reflection. These Polish-based results of reflexivity studies are coherent with the results obtained in other countries. At the time of the Polish study, Ko \& Aung (2015) studied 400 students in Burma with the use of a Reflexive Thinking Questionnaire and observed that statistically valid higher scores on the reflection scale $(\mathrm{t}$ $=3.27, \mathrm{p}<.01)$ and critical reflection scale $(\mathrm{t}=2.94, \mathrm{p}<.01)$ were obtained by full time students when compared to their part-time counterparts. At the same time, the tendency captured by the habitual action scale was reversed $(\mathrm{t}=-3.59, \mathrm{p}<.01)$.

\section{Correlation between reflexive thinking and participants' sex}

The results for the women and men on all the four scales were very close. Coherent results in this area were also obtained in studies by Phan (2007 and 2008) and Ghanizadeh, Jahedizadeh (2017), with no differences found in the reflexivity levels of women and men. Consistently, Ko \& Aung (2015) show no statistical significance between male and female participants. Mahasneh (2013), studying Jordanian students, also found no difference between male and female participants. The conclusion is that to date sex was found to have no impact on students' reflexivity levels.

\section{Conclusions}

The intention of the study was to attract attention to the importance of reflexivity, as an existing variable in higher education, which requires further 
investigation, and which should be reflected in the core curriculum, in teacher training, in lecturers' awareness and in classroom practice. Reflexivity was proven to be measurable and in the face of higher education reforms in Poland, with their unpredictability and potential for unintended consequences, it is a critical skill to navigate successfully through the unknown educational landscape, to actively adjust to changing conditions and to influence them. The findings demonstrated how the level of reflexive thinking is correlated with the level of study, confirming that students in higher years of study display higher levels of reflexivity. (cf. Ghanizadeh \& Jahedizadeh 2017).

\section{References}

Amidu, R.A. (2012). Exploring Real Estate Students' Learning Approaches, Reflective Thinking and Academic Performance. Paper presented at $48^{\text {th }}$ ASC Annual International Conference, Birmingham, UK. 11 April - 14 April 2012. ASC Proceedings of the Annual Conference. (p. 10).

Basol, G. \& Gencel E.E. (2013). Reflective Thinking Scale: A Validity and Reliability Study. Educational Sciences: Theory and Practice 13(2), 941-946.

Baxter Magolda, M.B. (1992). Knowing and Reasoning in College: gender related patterns in students' intellectual development. San Francisco: Jossey-Bass.

Boyd, L.D. (2008). Development of reflective judgment in the pre-doctoral dental clinical curriculum. European Journal of Dental Education, 12, 149-158. DOI: 10.1111/j.16000579.2008.00511.x

Boud, D., Keogh R., \& Walker D. (1985). Reflection: Turning Experience into Learning, London: Kogan Page.

Dawe, G., Jucker, R. \& Martin, S. (2005) Sustainable development in higher education: Current practice and future developments. A report for the Higher Education Academy. Dewey, J. (1910). How we think. Boston, DC: Health and Company.

Espinosa E.B. \& Mata J.G., (2008). Changes in the level of reflective thinking of prospective primary teachers of English over the practicum. In C. Harris \& J.M. Pinar Sanz (Eds.) New Tendency in English Teacher Education

Fischer, K.W., \& Pruyne, E. (2002). Reflective thinking in adulthood: Emergence, development, and variation. In J. Demick \& C. Andreoletti (Eds.) The Handbook of Adult Development (pp. 169-198). New York: Plenum.

Ghanizadeh, A. \& Jahedizadeh, S. (2017). Validating the Persian Version of Reflective Thinking Questionnaire and Probing Iranian University Students' Reflective Thinking and Academic Achievement. International Journal of Instruction, 10(3), 209-226.

https://doi.org/10.12973/iji.2017.10314a

Kadivar P., Tanha Z., Farzad V. (2012), The Relationship between epistemological beliefs, learning approaches, reflective thinking and academic achievement. Journal of Psychology 16, 251-65. 
Kalk, K., Luik, P., Taimalu, M., \& Täht, K. (2014). Validity and reliability of two instruments to measure reflection: A confirmatory study. Trames: A Journal of the Humanities and Social Sciences, 18(2), 121-134.

King, P., \& Kitchener, K.S. (2004). Reflective judgment: Theory and research on the development of epistemic assumptions through adulthood. Educational Psychologist, 39, 5-8.

Kember, D., Leung, D., Jones, A., \& Loke, A.Y. (2000). Development of a Questionnaire to measure the Level of Reflective Thinking. Assessment and Evaluation in Higher Education, 25(4), 382-395.

Ko, H.H., \& Aung P. Ei P., (2015). The Study of Reflective Thinking of University Students. Yangon University of Education Research Journal, 5, 1, 1-16.

Lucas, U., \& Leng Tan, P. (2006). Assessing levels of reflective thinking: the evaluation of an instrument for use within accounting and business education. Retrieved from

www2.uwe.ac.uk/faculties/BBS/BUS/Research/DRC/prhe.pdf [accessed 23.04.2017].

Mahasneh, A.M. (2013). The relationship between Reflective Thinking and Learning Styles among Sample of Jordanian University Students. Journal of Education and Practice, $4(21), 50-56$.

Mezirow, J. (1991). Transformative dimensions of adult learning. San Francisco: Jossey-Bass.

Naghdipour B. \& Emeagwali O.L. (2013). Assessing the Level of Reflective Thinking in ELT Students, Procedia-Social and Behavioral Sciences 83, 266-271.

Phan, H.P. (2007). Examination of student learning approaches, reflective thinking, and self-efficacy beliefs at the University of the South Pacific: A path analysis. Educational Psychology, 27(6), 789-806.

Phan, H.P. (2008). Unifying different theories of learning: Theoretical framework and empirical evidence. Educational Psychology, 28(3), 325-340.

Paul R. \& Elder L. (2002). Critical Thinking: Tools for Taking Charge of your Professional and Personal Life. Saddle River, NJ: Pearson Education Inc.

Rogers, R.R. (2001). Reflection in higher education: A conceptual analysis. Innovative Higher Education, 26 (1), 37-57.

Schön, D. (1983). The Reflective Practitioner, Basic Books, New York,

Snyder L.G. \& Snyder,M.J. (2008). Teaching Critical Thinking and Problem Solving Skills, The Delta Pi Epsilon Journal L (2), 90-99.

Thorpe, K. (2004). Reflective learning journals: from concept to practice. Reflective Practice 5 (3), 328-343.

Yuen Lie Lim, L.A. (2011). A comparison of students' reflective thinking across different years in a problem-based learning environment, Instructional Science, 39(2), 171-188. 